\title{
TANTANGAN DI ERA 4.0 PADA PENYAJIAN PROGRAM TELEVISI TERHADAP PENGGUNAAN BAHASA INDONESIA
}

\author{
Eka Septiani \\ Fakultas Matematika dan IPA, Universitas Indraprasta PGRI Jakarta \\ ekaseptiani87@yahoo.co.id.083898609291
}

\begin{abstract}
ABSTRAK
Media televisi merupakan satu di antara tantangan yang saat ini kita hadapi di era 4.0. Tantangan yang kita hadapi melalui media televisi antara lain adalah bagaimana kita dapat memilih program tayangan televisi yang mendidik terutama yang masih mengedepankan penggunaan bahasa Indonesia yang baik dan benar dalam penyajiannya. Ironisnya, sebagian besar program televisi yang disajikan tidak lagi mengindahkan bahasa Indonesia yang baku. Penelitian ini bertujuan untuk mengetahui bagaimana remaja dalam hal ini adalah mahasiswa dapat memandang dan memilih program televisi yang mereka tonton setiap harinya. Berdasar pada tujuan tersebut, peneliti menggunakan metode analisis deskriptif melalui kuisioner. Sampel yang dipilih diambil sebanyak 30 mahasiswa secara acak. Hasil analisis didapatkan data bahwa program televisi saat ini merupakan tantangan di era 4.0 dan sangat berpengaruh terhadap penggunaan bahasa Indonesia yang baku di kalangan remaja. Program televisi saat ini banyak yang belum mendidik lagi terutama dalam segi bahasa dalam penayangannya sehingga hal ini menjadi sebuah tantangan bagi para remaja agar mereka mampu menjaga penggunaan bahasa Indonesia yang baik dan benar.
\end{abstract}

Kata kunci: program televisi, tantangan era 4.0, pergeseran bahasa Indonesia

\begin{abstract}
Television media is one of the challenges we are currently facing in era 4.0. The challenge that we face through television media are, among other things, how we can choose educational television programs, especially those that still prioritize the use of Indonesian language that is good and correct in its presentation. Ironically, most television programs presented no longer heed the standard Indonesian language. This study aims to find out how teenagers in this case are students can view and choose television programs that they watch every day. Based on these objectives, researchers used descriptive analysis methods through questionnaires. The selected sample was taken as many as 30 student randomly. From the result of the analysts, the data shows that television programs are currently very influential in facing challenge in era 4.0 againts the standard use of Indonesian among teenagers. Today's television programs are lacking especially in terms of language in the screening so that it becomes a challenge for teenagers so that they are able to maintain the use of goog and correct Indonesian.
\end{abstract}

Keywords: television programs, the challenge of era 4.0, Indonesian language shift 


\section{PENDAHULUAN}

\section{Latar Belakang}

Revolusi Industri 4.0 secara umum diketahui sebagai perubahan cara kerja yang menitikberatkan pada pengolahan data, sistem kerja industri melalui kemajuan teknologi, komunikasi, dan peningkatan efisiensi kerja yang berkaitan dengan interaksi manusia. Lahirnya revolusi industri 4.0 ini merupakan dampak dari arus globalisasi yang sudah tidak terbendung lagi di negara kita, Indonesia. Revolusi industri keempat atau industri 4.0 merupakan pintu masuknya era digitalisasi yang merujuk pada gambaran situasi baik perubahan gaya hidup dan perilaku individu maupun organisasi saat ini. Kondisi ini disebabkan oleh revolusi teknologi sehingga berimplikasi besar pada masyarakat (Moriar, 2017). Dalam bukunya yang berjudul The Fourth Industrial Revolution, Schawab (2017) menjelaskan revolusi industri 4.0 telah mengubah hidup dan kerja manusia secara fundamental. Dampak yang ditimbulkan akibat arus globalisasi ini menyebar luas seiring dengan kemajuan media massa, salah satunya adalah media televisi.

Media televisi merupakan media massa elektronik yang mampu menyebarkan informasisecara cepat dan mampu mencapai khalayak dalam waktu bersamaan dengan berbagai macam tayangan mulai dari infotainment, entertainment, iklan hingga sinetron dan film. Televisi memiliki efektivitas dan efisiensi besar dalam memengaruhi pikiran, perasaan, emosi bahkan karakter serta perilaku seseorang sehari-hari. Pada dasarnya media televisi memiliki peranan pokok yaitu memberikan informasi atau pesan yang mengandung unsur pendidikan, penerangan, hiburan dan promosi. Siaran televisi pertama kali ditayangkan di Indonesia pada tanggal 17 Agustus 1962 untuk meliput upacara peringatan hari Proklamasi di Istana Negara.

Siaran televisi mulai ditayangkan secara terus menerus sejak tanggal 24 Agustus 1962 dengan TVRI sebagai satu-satunya stasiun televisi yang ada. Kemudian, tahun 1989 pemerintah mulai memberi izin didirikannya stasiun televisi swasta. Seiring perkembangan zaman, muncul berbagai stasiun televisi swasta yang bisa disaksikan di Indonesia. Di antaranya adalah tayangan sinetron yang mulai bermunculan di tahun 1990. Kemudian pada tahun 1995-1998 tema pada sinetron mulai mengadaptasi dari film layar lebar. Pada tahun 1998 kebanyakan sinetron yang diproduksi merupakan adaptasi dari novel-novel terkenal di Indonesia. Sejak tahun 1999 hingga saat ini, tema sinetron lebih beragam dan lebih suka menggambarkan kehidupan dunia modern.

Dalam rangka menarik perhatian khalayak sebanyak mungkin guna mempertahankan eksistensinya, para penyelenggara siaran berlomba menyajikan tayangan sinetron semenarik mungkin. Kini banyak dijumpai tayangan sinetron yang menggunakan bahasa Indonesia yang digabungkan dengan bahasa asing atau bahkan bahasa gaul yang dianggap lebih komunikatif dan modern. Penggunaan bahasa Indonesia yang baik dan benar dalam setiap penayangannya terkesan tidak lagi diindahkan sehingga hal inilah yang menjadi tantangan bagi media massa terutama televisi di era industri 4.0 untuk mampu mempertahankannya.

\section{Rumusan Masalah}

Rumusan masalah dalam penelitian ini adalah sebagai berikut.

1. Seberapa besar intensitas remaja menikmati program tayangan di televisi.

2. Seberapa besar pengaruh tayangan televisi terhadap penggunaaan bahasa Indonesia yang baku di kalangan remaja.

3. Seberapa besar intensitas penggunaan bahasa Indonesia yang baku dalam komunikasi seharihari remaja. 


\section{Tujuan}

Tujuan penulisan makalah ini seperti berikut.

1. Mengetahui adanya pengaruh tayangan televisi terhadap penggunaan bahasa Indonesia yang baku di kalangan remaja.

2. Mengetahui pengaruh tayangan televisi terhadap penggunaan bahasa Indonesia yang baku di kalangan remaja

3. Mengetahui besar intensitas penggunaan bahasa Indonesia yang baku dalam komunikasi sehari-hari remaja.

\section{Tinjauan Pustaka}

Revolusi Industri dimulai dari industri 1.0,2.0,3.0, hingga industri 4.0. Industri 4.0 selanjutnya hadir menggantikan industri 3.0 yang ditandai dengan cyber fisik dan kolaborasi manufacturing (Irianto, 2017). Saat ini kita berada pada Abad XXI. Abad sekarang ini sedang berlangsung Revolusi Industri Keempat, Revolusi Digital, dan Revolusi Ilmu Pengetahuan, yang sangat mendasar mengubah dunia manusia, bahkan alam semesta. Di sinilah kita memasuki masa yang memberikan banyak tantangan. Lebih spesifik Heckeu et al. (2016) memaparkan tantangan industri 4.0 sebagai berikut.

Tabel 1 Tantangan Industri 4.0

\begin{tabular}{|l|l|}
\hline Tantangan Ekonomi & 1. Globalisasi yang terus berlanjut: \\
a. Keterampilan antarbudaya \\
b. Kemampuan berbahasa \\
c. Fleksibelitas waktu \\
d. Keterampilan jaringan \\
e. Pemahaman proses \\
2. Meningkatkan Kebutuhan akan inovasi: \\
a. Pemikiran wirausaha \\
b. Kreativitas \\
c. Pemecahan masalah \\
d. Bekerja di bawah tekanan \\
e. Pengetahuan mutakhir \\
f. Keterampilan teknis \\
g. Keterampilan penelitian \\
h. Pemahaman proses \\
3. Permintaan untuk orientasi layanan yang lebih tinggi: \\
a. Pemecahan konflik \\
b. Kemampuan komunikasi \\
c. Kemampuan berkompromi \\
d. Keterampilan berjejaring \\
4. Tumbuh kebutuhan untuk kerja sama dan kolaboratif: \\
a. Mampu berkompromi dan kooperatif \\
b. Kemampuan bekerja dalam tim \\
c. Kemampuan komunikasi \\
d. Keterampilan berjejaring \\
\end{tabular}




\begin{tabular}{|c|c|}
\hline Tantangan Sosial & $\begin{array}{l}\text { 1. Perubahan demografi dan nilai sosial: } \\
\text { a. Keterampilan mentransfer pengetahuan } \\
\text { b. Penerimaan rotasi tugas kerja dan perubahan } \\
\text { pekerjaan yang terkait (toleransi ambiguitas) } \\
\text { c. Fleksibelitas waktu dan tempat } \\
\text { d. Keterampilan memimpin } \\
\text { 2. Peningkatan kerja virtual: } \\
\text { a. Fleksibelitas waktu dan tempat } \\
\text { b. Keterampilan teknologi } \\
\text { c. Keterampilan media } \\
\text { d. Pemahaman keaman TI } \\
\text { 3. Pertumbuhan kompleksitas proses: } \\
\text { a. Keterampilan teknis } \\
\text { b. Pemahaman proses } \\
\text { c. Motivasi belajar } \\
\text { d. Toleransi ambiguitas } \\
\text { e. Pengambilan keputusan } \\
\text { f. Penyelesaian masalah } \\
\text { g. Keterampilan analisis }\end{array}$ \\
\hline Tantangan Teknis & $\begin{array}{l}\text { 1. Perkembangan teknologi dan penggunaan data } \\
\text { eksponensial: } \\
\text { a. Keterampilan teknis } \\
\text { b. Kemampuan analisis } \\
\text { c. Efisiensi dalam bekerja dengan data } \\
\text { d. Keterampilan koding } \\
\text { e. Kemampuan memeahami keamanan TI } \\
\text { f. Kepatuhan } \\
\text { 2. Menumbuhkan kerja kolaboratif: } \\
\text { a. Mampu bekerja dengan tim } \\
\text { b. Kemampuan komunikasi virtual } \\
\text { c. Keterampilan media } \\
\text { d. Pemahaman keamanan TI } \\
\text { e. Kemampuan untuk bersikap kooperatif }\end{array}$ \\
\hline Tantangan Lingkungan & $\begin{array}{l}\text { Perubahan iklim dan kelangkaan sumber daya: } \\
\text { a. Pola pikir berkelanjutan } \\
\text { b. Motivasi menjaga lingkungan } \\
\text { c. Kreativitas untuk mengembangkan solusi } \\
\text { berkelanjutan baru }\end{array}$ \\
\hline $\begin{array}{c}\text { Tantangan Politik dan } \\
\text { Aturan }\end{array}$ & $\begin{array}{l}\text { 1. Standardisasi: } \\
\text { a. Keterampilan teknis } \\
\text { b. Keterampilan koding } \\
\text { c. Pemahaman proses } \\
\text { 2. Keamanan data dan privasi: } \\
\text { a. Pemahaman keamanan teknologi informasi } \\
\text { b. Kepatuhan }\end{array}$ \\
\hline
\end{tabular}


Satu di antara tantangan yang cukup membawa pengaruh yang sangat besar adalah melalui media massa televisi terutama pada penyajian program tayangan televisi terhadap penggunaan bahasa.

\section{a. Televisi}

Pada hakikatnya media televisi hadir karena perkembangan teknologi. Bermula dari ditemukannya electriche teleskop sebagai perwujudan gagasan seorang mahasiswa dari Berlin (Jerman Timur) yang bernama Paul Nipkov. Hal ini terjadi antara tahun 1883--1884. Akhirnya Nipkov diaakui sebagai "Bapak Televisi".

Televisi adalah alat perangkat siaran bergambar, yang berupa audio visual dan penyiaran videonya, secara broadcasting. Istilah ini berasal dari bahasa Yunani, yitu tele (jauh) dan vision (melihat), jadi secara harfiah berarti "melihat jauh" karena pemirsa berada jauh dari studio tv (Zoebazary, 2010:255). Sementara itu, menurut Badjuri (2010:39) Televisi adalah media pandang sekaligus media pendengar (audio-visual), yang di mana orang tidak hanya memandang gambar yang ditayangkan televisi, tetapi sekaligus mendengar atau mencerna narasi dari gambar tersebut. Berdasar uraian di atas dapat disimpulkan bahwa televisi merupakan salah satu media massa elektronik yang dapat menyiarkan siarannya dalam bentuk gambar atau video serta suara yang berfungsi memberi informasi dan hiburan kepada khalayak luas.

Siaran televisi di Indonesia pertama kali bernama TVRI (Televisi Republik Indonesia) ditayangkan pertama kali pada tanggal 17 Agustus 1962 yang bertepatan dengan peringatan Hari Kemerdekaan Republik Indonesia yang ke-17. Pada saat itu, siaran hanya berlangsung mulai pukul 07.30 sampai dengan pukul 11.02 WIB untuk meliput upacara peringatan hari Proklamasidi Istana Negara. Siaran televisi secara kontinyu dimulai sejak tanggal 24 Agustus 1962 dan mampu menjangkau seluruh provinsi yang ada pada waktu itu. Seiring dengan kemajuan demokrasi dan kebebasan untuk berekspresi, pada tahun 1989 pemerintah mulai membuka kran izin untuk mendirikan televisi swasta. Adanya perkembangan ini menimbulkan peluang bagi pihak swasta untuk mengembangkan stasiun televisi baru. Di tanggal 24 Agustus 1989, lahirlah stasiun televisi kedua di Indonesia bernama Rajawali Citra Televisi (RCTI). Dilanjutkan dengan hadirnya stasiun-stasiun televisi lainnya.

Di era globalisasi sekarang ini pemerintah membuka kebijakan untuk membuka selebarlebarnya kebebasan pers. Hal ini menimbulkan suasana baru di bidang jurnalistik cetak maupun elektronik tidak terkecuali media televisi. Akibat dari perkembangan teknologi komunikasi masaa televisi, maka akan memberikan pengaruh dalam bidang politik,ekonomi, sosial, budaya, bahkan pertahanan dan keamanan negara.

Hanya saja seiring perkembangan zaman hadirnya televisi membawa pengaruh. Hal ini pernah disampaikan oleh Menteri Komunikasi dan Informatika Tifatul Sembiring mengkritik sejumlah tayangan program televisi yang dinilai tidak mendidik, khususnya bagi anak-anak. Usai membuka pameran penyiaran Indonesia Broadcasting Expo di Jakarta, Kamis (18/4), Tifatul mengatakan mendapat banyak mendapat masukan dari masyarakat seputar tayangan stasiun televisi yang tidak mendidik tersebut. "Keluhan dari masyarakat, banyak tayangan yang tidak mendidik termasuk masih adanya tayangan-tayangan yang belum disensor buat anak-anak. Terutama jam tayangnya. Adakalanya karena tidak bisa dipisah, acara itu lanjut terus. Mestinya diberi peringatan," ujar Tifatul. "Menjelang magrib, misalnya, antara jam 4 sampai 6 petang itu kan saat anak-anak belajar. Seharusnya tidak diputar film kartun pada jam-jam itu... sangat mengganggu sekali. Mungkin film kartun itu diputar saat anak-anak istirahat. Jadi apa yang ditayangkan di televisi itu aman buat dewasa dan anak-anak."

Untuk ke depannya, menurut Tifatul, Komisi Penyiaran Indonesia (KPI) perlu membuat aturan standar program termasuk sanksi buat stasiun televisi yang melanggar aturan itu. "Bahwa ke depannya saya dengar KPI akan menerapkan sanksi administratif terhadap pelanggaran- 
pelanggaran itu, seperti denda misalnya. Jadi tidak hanya terguran atau peringatan," ujarnya. Tifatul juga menyoroti tayangan hiburan seperti sinetron, acara gosip dan berita yang menurutnya memerlukan evaluasi agar lebih lebih bermanfaat dan mendidik buat masyarakat.

KPI mengaku Undang-Undang No. 32/2002 tentang penyiaran belum mengatur secara tegas sanksi bagi stasiun televisi yang menayangkan program yang tidak mendidik. Komisioner KPI Dadang Rahmat Hidayat mengatakan penerapan sanksi itu tidak mematikan sebuah lembaga penyiaran. "Kewenangan yang sekarang hanya sebatas sanksi administratif yaitu penghentian sementara mata acara. Ini adalah salah satu problem dalam undang-undang itu. Tapi kami juga berharap bukan berarti munculnya sanksi yang mematikan sebuah lembaga penyiaran. Yang penting bagaimana perlindungan publik bisa lebih baik lagi ke depannya," ujarnya. Dari data KPI, pada 2012 program televisi yang bermasalah ada sekitar 20-22 persen. Program tayangan yang cukup mendidik ada sekitar 20 - 25 persen. Dan program tayangan yang biasa-biasa saja alias tidak bermasalah ada sekitar 40 -- 45 persen

\section{b. Remaja dan Acara Televisi}

Sering dengan mudah orang mendefinisikan remaja sebagai periode transisi antara masa anak-anak ke masa dewasa, atau masa usia belasan tahun atau jika seseorang menunjukkan tingkah laku tertentu seperti susah diatur, mudah tersinggung, mudah terangsang perasaannya, dan sebagainya (Prawirohardjo, 2010:2). Menurut Yusuf (2011:184) fase remaja merupakan segmen perkembanga individu yang sangat penting, yang diawali dengan matangnya organorgan fisik (seksual) sehingga mampu bereproduksi. Menurut Konopka masa remaja ini meliputi (a) remaja awal: 12--15 tahun; (b) remaja madya: 15--18 tahun; (c) remaja akhir: 19--22 tahun.

Pada hakikatnya remaja erat kaitannya dengan televisi. Televisi merupakan media yang dianggap paling mempengaruhi masyarakat dalam hal penyampaian informasi. Informasi yang diberikan dikemas dalam bentuk sebuah program acara. Di samping memudahkan dalam mengetahui berbagai informasi, di sisi lain televisi juga membawa suatu dampak negatif seperti kekerasan dan unsur pornografi di berbagai lapisan masyarakat, terutama anak-anak dan remaja yang mudah terpengaruh dengan apa yang dilihatnya. Di luar itu juga sebagai pemenuhan kebutuhan masyarakat akan rasa ingin tahunya terhadap lingkungan disekitar.

Media massa bisa mempengaruhi siapa saja karena pada dasarnya dalam jiwa manusia ada manusia yang kurang krisis dan cenderung untuk menerima semua sajian yang diberikan. Sehingga masyarakat merasa membutuhkan televisi yang mengakibatkan waktu luang mereka dihabiskan hanya untuk menonton acara televisi, khususnya pada kalangan remaja. Kegemaran remaja dalam menonton televisi dapat mempengaruhi perilaku remaja dari acara yang mereka tonton. Sangat mudahnya remaja terpengaruh oleh acara yang mereka lihat di televisi dapat disebabkan oleh masa remaja yang merupakan masa transisi menuju masa dewasa. Pada masa transisi tersebut remaja memiliki tingkat emosional yang belum stabil sehingga sangat mudah dipengaruhi oleh lingkungan di sekitarnya.

Sebenarnya banyak hal positif yang dapat kita peroleh dari media seperti informasi dan pengetahuan.Tetapi yang sangat disayangkan kita lebih banyak menyerap dan menyukai sajian yang kurang layak untuk dikonsumsi oleh remaja dan anak. Apabila sebagai remaja dan terbiasa mengonsumsi media semacam itu, akan berdampak buruk terhadap pola pikir remaja. Karena mereka masih belum dapat memilih mana tayangan yang patut untuk ditonton dan yang tidak. Tayangan yang tidak sepatutnya ditonton oleh anak-anak dan remaja dapat mempengaruhi perilaku mereka. Orang tua atau keluarga berperan besar dalam mengontrol tayangan yang dikonsumsi oleh anak-anak dan remaja.

Keluarga memberi pengaruh terpenting dalam kehidupan anak; namun di lain pihak media dalam berbagai bentuknya termasuk televisi, komputer, ponsel, tablet dan sebagainya juga sangat dekat dengan anak. Oleh karena media dapat mempengaruhi bagaimana anak berpikir, merasa dan berperilaku, the American Academy of Pediatrics (Media and Your Family: Television and Other Screens, 2013) mendorong orang tua untuk menolong anak-anak mereka membentuk kebiasaan menggunakan media secara sehat sejak awal. 
Ada beberapa manfaat yang bisa diperoleh ketika anak menonton tayangan televisi yang berkualitas, yaitu televisi memberikan alasan untuk menghabiskan waktu bersama keluarga. Orangtua tetap dapat menerapkan batasan dalam menyaksikan tayangan televisi sekaligus menjadwalkan waktu menonton bersama untuk menciptakan ikatan emosional antara anak dengan orang tua, misalnya menemani si kecil menonton Club Mickey Mouse di Disney channel sambil berinteraksi melakukan aktivitas seru.

Konsistensi orang tua dalam menyeleksi tayangan televisi tetap dibutuhkan sampai pada saatnya nanti anak-anak yang beranjak remaja sudah cukup mampu memilah tayangan yang tepat bagi dirinya sendiri. Di masa kini, orangtua bisa melihat kekuatan dari teknologi, di mana teknologi baru sebetulnya dapat membantu anak tumbuh, terhubung. Tayangan televisi bisa menjadi sarana untuk lebih dekat dengan anak, dengan tidak melepaskan tanggung jawab orang tua, sepanjang penggunaannya sesuai dengan kapasitasnya dan bukan menjadikan televisi sebagai babysitter.

Jadikan televisi sebagai media yang melekatkan hubungan. Salah satu manfaat yang paling besar dan sangat penting adalah ketika orang tua memiliki kesempatan untuk berbicara dengan anak mengenai apa yang mereka tonton. Jadi, bukan hanya sekadar menonton bersama atau hanya berbicara tentang tontonan tersebut dikatakan mencukupi tetapi sinergi dari keduanya adalah kata kunci.

Televisi mempunyai pengaruh yang besar dalam tumbuh kembang remaja, karena sekarang ini sebagian besar waktu remaja dihabiskan dengan menonton televisi. padahal menonton televisi mempunyai banyak pengaruh terhadap remaja baik yang positf maupun yang negatif. Dampak positif kita bisa memperoleh berbagai informasi yang kita butuhkan dengan mudah dan cepat. Televisi mampu membuat orang mengingat apa yang mereka lihat dan dengar dilayar televisi walau hanya sekali ditayangkan. Dari dampak positif di atas berikut dampak negatif menonton televisi seperti berikut.

a. Berpengaruh terhadap perkembangan otak,

b. Berpengaruh terhadap sikap,

c. Mengurangi semangat belajar,

d. Merenggangkan hubungan antaranggota keluarga, dan

e. Matang secara seksual lebih cepat.

Kesimpulannya televisi adalah media masa yang paling digemari masyarakat. Namun, televisi mempunyai banyak pengaruh terhadap perkembangan remaja, sebagai media informasi yang mudah dan cepat tetapi tidak banyak acara televisi yang kontennya mendidik. Apabila tontonan seperti itu ditonton oleh para remaja dan anak-anak akan berdampak buruk bagi perkembangan mental mereka. Dengan demikian, dapat membuktikan bahwa televisi bisa memberi dampak buruk. Remaja sekarang sangat penting untuk mempunyai kesempatan belajar dan mengembangkan keterampilan untuk menjadi sukses. Oleh karena itu, kita mulai sekarang perlahan perlu membatasi, mengawasi, dan mendampingi anak letika menonton tv. Bahasa

Bahasa menurut KBBI adalah sistem lambang bunyi yang arbitrer, digunakan oleh anggota suatu masyarakat untuk bekerja sama, berinteraksi, dan mengidentifikasi diri. Bahasa Indonesia merupakan bahasa resmi bangsa Indonesia. Oleh karena itu, bahasa Indonesia mempunyai peranan penting dalam membangun manusia Indonesia seutuhnya. Seiring dengan adanya arus globalisasi, penggunaan dan keberadaan bahasa Indonesia di masyarakat ikut berimbas. Penggunaan bahasa di dunia maya, internet, bahkan media massa lainnya, memberi banyak perubahan bagi struktur bahasa Indonesia yang oleh beberapa pihak dinilai dapat merusak bahasa itu sendiri. Berlandaskan alasan globalisasi dan prestise, masyarakat mulai kehilangan rasa bangga menggunakan bahasa Indonesia. Sulit dipungkiri memang, bahasa asing kini telah menjamur penggunaannya. Kita pun lebih merasa bangga jika lancar berbicara bahasa asing. 
Namun, apapun alasannya, tanpa kita sadari secara perlahan kita telah ikut andil dalam mengikis kepribadian dan jati diri bangsa kita sendiri. Hal ini telah menyebabkan timbunya pergeseran dan pemertahanan bahasa.

Pergeseran dan pemertahanan bahasa merupakan dua sisi mata uang. Fenomena ini merupakan dua fenomena yang terjadi bersamaan. Bahasa menggeser bahasa lain atau bahasa yang tergeser oleh bahasa lain, bahasa yang tergeser adalah bahasa yang tidak mampu mempertahankan diri (Sumarsono, 2011). Kondisi tersebut terjadi pada saat suatu masyarakat (komunitas bahasa) memilih untuk menggunakan atau meninggalkan pemakaian suatu bahasa. Hal yang serupa juga disampaikan oleh Fasold (dalam Lukman: 2000) mengungkapkan bahwa pergeseran dan pemertahanan bahasa ibarat dua sisi mata uang yang tidak dapat dipisahkan satu sama lainnya. Dia merupakan hasil kolektif dari pilihan bahasa (language choice). Pemertahanan bahasa, masyarakat secara kolektif menentukan untuk melanjutkan memakai bahasa yang sudah biasa dipakai. Ketika sebuah masyarakat memilih bahasa baru di dalam ranah yang semula digunakan bahasa lama, pada saat itu merupakan kemungkinan terjadinya proses sebuah pergeseran bahasa.

Sekarang ini penggunaan bahasa Inggris sudah banyak menggejala. Di bidang komunikasi kita banyak menggunakan kata mendownload,mengupload, mengupdate, dienter, didelete, dan lain-lain. Selain bahasa Asing, kedudukan bahasa Indonesia juga semakin terdesak dengan pemakaian bahasa gaul di kalangan remaja. Misalnya dalam kalimat "gue gitu loh" atau "ya gak lah keles". Fenomena ini mungkin saja merupakan keadaan yang disebut perubahan, pergeseran, atau pemertahanan bahasa. Fenomena pergeseran bahasa ini juga hadir dari adanya program tayangan televisi.

Para pendidik di Bandar Lampung, Jumat (16/11), menilai, penggunaan Bahasa Indonesia pada film-film dan sinema elektronik (sinetron) di televisi di Indonesia cenderung sangat kasar, tidak mendidik, serta cenderung mengajarkan anak-anak dan remaja berbahasa buruk dan berperilaku kurang baik. Penilaian terhadap film dan sinetron Indonesia itu, diungkapkan pada Sosialisasi Rancangan Undang-Undang Kebahasaan oleh Pusat Bahasa melalui Kantor Bahasa Provinsi Lampung yang disampaikan Sukiman (Pusat Bahasa) dan Tim, serta Agus Sri Danardana (Kepala Kantor Bahasa Lampung).

Sejumlah guru Bahasa Indonesia menyebutkan contoh beberapa film dan sinetron Indonesia disiarkan umumnya televisi swasta yang kerapkali menggunakan bahasa yang dinilai "vulgar", serampangan, kasar, dan tidak layak didengar terutama oleh anak-anak dan generasi muda bertaburan setiap saat. Salah satu guru sampai memantau penggunaan bahasa pada sinetron di televisi itu, setidaknya setiap hari terdapat 100-an buah kata yang tergolong kasar dan tidak pantas didengar justru digunakan setiap hari dan dapat dengan mudah ditonton anak-anak maupun generasi muda. "Kalau dibiarkan bukan saja akan merusak kaidah bahasa Indonesia, tapi bahkan bisa membuat anak-anak kita menjadi berbahasa dan berperilaku buruk," kata Yusuf, salah satu pendidik itu pula. Dia justru membandingkan dengan penggunaan bahasa yang disulihbahasakan dari sinetron asing ke dalam Bahasa Indonesia yang lebih baik, santun, dan menerapkan kaidah Bahasa Indonesia yang baik dan benar. "Kenapa sinetron atau film asing bahasanya malah lebih bagus, sopan dan santun, tapi film dan sinetron kita yang kasar dan sembarangan malah dibiarkan saja," tanya dia lagi.

Pusat Bahasa diharapkan dapat menertibkan dan mengambil tindakan yang diperlukan agar penayangan sinetron dan film yang kerap menggunakan bahasa kasar dan kurang mendidik itu, dapat ditertibkan. Dalam ketentuan draf RUU Kebahasaan, pengaturan dalam penggunaan Bahasa Indonesia, bahasa asing, dan bahasa daerah terutama untuk para pejabat publik, penggunaan kata-kata dan kalimat nama-nama tempat umum, penggunaan bahasa di media massa yang harus memenuhi ketentuan kaidah bahasa yang baik dan benar. Namun untuk kepentingan kesenian dan sastra, agama, adat istiadat, dinyatakan tidak berlaku aturan penggunaan bahasa Indonesia yang baku, baik dan benar.

\section{METODE PENELITIAN}


Metode yang digunakan dalam penelitian ini adalah metode penelitian analisis deskriptif. Penelitian analisis deskriptif adalah salah satu jenis penelitian yang bertujuan menyajikan gambaran lengkap dengan cara menganalisis mengenai setting sosial untuk mengeksplorasi dan mengklarifikasi suatu fenomena atau kenyataan sosial, dengan jalan mendeskripsikansebuah variable yang berkenaan dengan masalah dan unit yang diteliti antara fenomena yang diuji. Penelitian ini bersifat deskriptif berdasr pada data yang terhimpun dan disusun secara sistematik, faktual, dan cermat. Penelitian ini hanya memaparkan situasi atau peristiwa berdasar pada data tersebut. Di sini peneliti tidak mencari dan menjelaskan hubungan, tidak menguji hipotesis, atau membuat prediksi. Melalui penelitian analisis deskriptif, peneliti berusaha mendeskripsikan tentang pengaruh tayangan televisi di Indonesia terhadap pergeseran penggunaan bahasa Indonesia yang baku di kalangan remaja.

Populasi penelitian adalah sekelompok data dengan karakteristik tertentu. Dalam populasi dijelaskan secara spesifik tentang sasaran penelitian tersebut. Sampel adalah sejumlah anggota yang dipilih dari populasi atau bagian kecil dari populasi. Target populasi dalam penelitian adalah remaja dengan status mahasiswa Program Studi Pendidikan Matematika kelas reguler di Universitas Indraprasta PGRI. Sampel yang diambil dalam penelitian ini terdiri atas tiga kelas reguler sejumlah 30 orang. Berikut merupakan nama-nama responden yang dipilih dalam penelitian ini.

Tabel 2 Data Responden

\begin{tabular}{|l|l|}
\hline $\begin{array}{l}\text { Kela } \\
\text { s }\end{array}$ & Nama Responden \\
\hline R3D & Eka Agustia Ningsih \\
\hline R3C & Annisa Yulianti \\
\hline R3D & Diyan Fitrianti \\
\hline R3A & Shafira Isma Amalia \\
\hline R3A & Arieska Cessey D.C. \\
\hline R3A & Sulvia \\
\hline R3C & Muhammad Halim Dwi Kusuma \\
\hline R3C & Nathasya Farah \\
\hline R3C & Vilandina Alif Kamin \\
\hline R3C & Altru Wisesa \\
\hline R3A & Estevanus Paparang \\
\hline R3A & Dinda Nurfaiqoh \\
\hline R3D & Amalia Nur Fatihah \\
\hline R3C & Della Safitri \\
\hline R3D & Dedeh Ramadhatun \\
\hline
\end{tabular}

\begin{tabular}{|l|l|}
\hline $\begin{array}{l}\text { Kela } \\
\mathrm{s}\end{array}$ & Nama Responden \\
\hline R3D & Vicka Yuniar Warsito \\
\hline R3D & Prismawinda Anniva Nuthqi \\
\hline R3D & Ismi Suryani \\
\hline R3C & Muhammad Ikhsan \\
\hline R3C & Monika Clara Noviati \\
\hline R3C & Evie Kristina \\
\hline R3A & Jennei Kautami Nugraha \\
\hline R3A & Febby Ariyanti \\
\hline R3C & Clara Angelina \\
\hline R3C & Muhammad Faozan \\
\hline R3D & Momin Bahta \\
\hline R3D & Mega Woro Sekar Indah \\
\hline R3D & Nadia Juniati \\
\hline R3D & Laras Febriyanti \\
\hline R3D & Antonius Alvin \\
\hline
\end{tabular}

Sumber: Data Pribadi 
Teknik pengumpulan data yang digunakan dalam penelitian ini adalah data sekunder dan data primer. Sumber data sekunder adalah sumber data yang tidak langsung memberikan data kepada pengumpul data (Sugiono, 2008:402). Data sekunder ini merupakan data yang sifatnya mendukung keperluan data primer seperti buku-buku, literatur dan bacaan.

Pengumpulan data sekunder terkait pengaruh tayangan televisi di Indonesia terhadap pergeseran penggunaan bahasa Indonesia yang baku di kalangan remaja dan dapat ditelusuri melalui berbagai hasil penelitian yang terkait pengaruh sinetron dengan bahasa modern atau gaul. Data primer ialah data yang berasal dari sumber asli atau pertama. Data ini tidak tersedia dalam bentuk terkompilasi ataupun dalam bentuk file-file. Data ini harus dicari melalui narasumber atau dalam istilah teknisnya responden, yaitu orang yang dijadikan objek penelitian atau orang yang kita jadikan sebagai sarana mendapatkan informasi ataupun data (Umi, 2008: 98). Teknik pengumpulan data primer diperoleh dengan cara memberi daftar pertanyaan (kuesioner) kepada responden. Metode kuosioner dilakukan secara tertulis yang difokuskan pada remaja yang berstatus mahasiswa Program Studi Pendidikan Matematika kelas reguler di Universitas Indraprasta PGRI.

Pada kuesioner tertulis tersebut terdapat beberapa pertanyaan, di antaranya adalah pertanyaan berupa pilihan yang bersifat tertutup dan tanggapan bersifat terbuka. Secara garis besar kuesioner memuat beberapa informasi, yaitu:

a. Identitas diri responden.

Identitas diri memuat informasi responden terkait nama lengkap, nomor induk mahasiswa, dan asal kelas romobongan belajar.

b. Perilaku responden.

Perilaku memuat pola kebiasaan responden terkait intensitas menonton sinetron selama satu minggu dan penggunaan bahasa Indonesia yang baku untuk komunikasi sehari-hari.

c. Tanggapan/ perspektif responden.

Tanggapan memuat informasi berupa perspektif dari responden tentang pergeseran penggunaan bahasa yang baku pada tayangan televisi di Indonesia.

Teknik analisis data yang dilakukan pada penelitian ini meliputi pengujian data, pengategorian, dan pengumpulan hasil kuesioner, serta pengombinasian bukti-bukti yang merujuk pada proporsi awal penelitian. Sejak data hasil kuesioner diperoleh peneliti langsung menganalisis. Hal ini bertujuan untuk mendapat suatu deskripsi, sehingga analisi harus dilakukan dengan cara mengomparasikan kategori dan data dengan teori-teori yang dijadikan acuan dalam penelitian ini. Data yang diperoleh dalam keseluruhan proses penelitian ini kemudian disajikan dalam bentuk uraian secara sistematis agar mudah dipahami.

\section{HASIL DAN PEMBAHASAN}

Berdasar pada hasil survei dari kuesioner yang peneliti sebar terhadap 30 orang kalangan remaja di Jakarta, menunjukkan intensitas mereka dalam menonton televisi 1--2 kali dalam seminggu sebanyak 17\%, 3--4 kali dalam seminggu sebanyak 6\%, lebih dari 4 kali dalam sehari sebanyak $30 \%$, dan jarang menonton televisi sebanyak $47 \%$. Intensitas menonton televisi pada remaja di Jakarta dapat dilihat pada diagram berikut. 


\section{Gambar 1.}

\section{Diagram Intensitas Menonton Televisi dalam Seminggu}

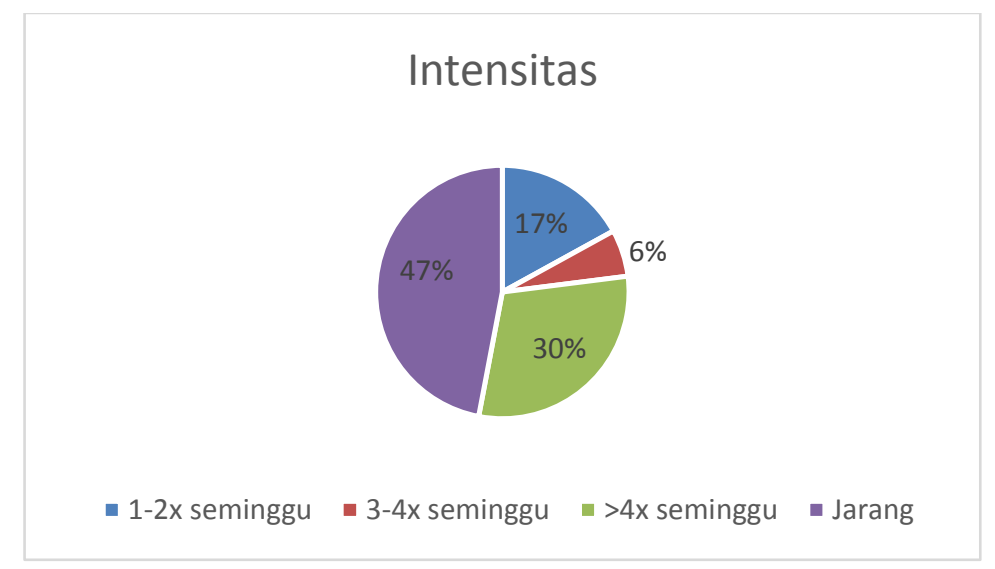

Sumber: Survei Primer, 2018

Sebanyak $47 \%$ dari remaja yang jarang menonton disebabkan oleh pandangan mereka bahwa beberapa acara televisi yang ada pada saat ini banyak yang kurang mendidik. Baik itu dari segi bahasa atau sajian program acaranya yang mereka anggap banyak yang tidak mengindahkan penggunaan bahasa Indonesia sehingga mereka enggan menonton televisi.

Selain mengetahui intensitas mereka dalam menonton televisi setiap minggunya, melalui penelitian ini dapat diketahui beberapa jenis acara televisi yang mendidik dan tidak mendidik menurut mereka. Dari beberapa acara televisi yang mereka anggap mendidik, peneliti memilih 5 acara televisi yang paling banyak mereka tonton. Contoh acara televisi yang mereka anggap mendidik seperti: Hitam Putih, Mata Najwa, On The Spot, Laptop Si Unyil, serta Adit dan Sopo Jarwo. Sedangkan 5 acara televisi yang mereka anggap kurang mendidik dan paling banyak mereka tonton seperti: Anak Langit, Anak Jalanan, Jangan Takut Jatuh Cinta, Katakan Putus, dan Sinetron lainnya.

\section{PENUTUP}

\section{Simpulan}

Berdasar pada hasil penelitian ini, peneliti dapat menyimpulkan bahwa intensitas remaja menonton televisi dapat dikatakan cukup besar. Hanya saja para remaja masih banyak yang menganggap hampir sebagian tayangan televisi banyak yang tidak mendidik baik dari segi bahasa maupun segi program acaranya.Simpulan yang dapat diambil untuk media massa itu sendiri, di era industri 4.0 tayangan televisi mendapat sebuah tantangan bagaimana dapat mempertahankan penggunaan bahasa Indonesia sehingga tidak membawa pengaruh yang buruk di kalangan anak-anak atau remaja.

\section{Saran}

Menyuguhkan program tayangan televisi perlu diperhatikan oleh beberapa pihak dalam menghadapi sebuah tantangan di era industri 4.0. Sebagai penikmat tayangan televisi, masyarakat dalam hal ini remaja harus selektif dalam memilih tayangan televisi. Pihak penyiaran juga harus dapat menyaring atau menyeleksi program tayangan sebelum dinikmati oleh masyarakat khususnya remaja. Hal ini bertujuan untuk mempertahankan penggunaan bahasa Indonesia yang mungkin saja membawa pengaruh buruk di kalangan remaja dalam menghadapi tantangan di era industri 4.0. 


\section{DAFTAR PUSTAKA}

Badjuri, Adi.2010.Jurnalistik Televisi.Yogyakarta: Graha Ilmu.

Hecklau, F,Galeiizke,M,Flach,S,\&Kohl,H. 2016. Holistic approach for human resource management in industry 4.0.ProcediaCIRP.54,1-6. http://doi.org/10.1016/j.procir.2016.05.102. (Diakses tanggal 17 Mei 2019).

Lukman.2000. Pemertahanan Bahasa Warga Transmigran Jawa di Wonomulyo Polmas. Disertasi. Pascasarjana Unhas.Makassar.

Prawirohardjo, Sarwono. 2010.Buku Acuan Nasional Pelayanan Kesehatan, Maternal dan Neonatal.Jakarta: PT Bina Pustaka.

Rabeh Moriar, Husam Arman, and Saeed Mousa, 2017. "The Fourth Industrial Revolution (Industry 4.0): A Social Innovation Perspective", Technology Innovation Perspective, hlm.1--10.(Diakses tanggal 20 Mei 2019).

Schawab, K. 2007.The Fourth Industry Revolution.Crown Business Press.

Sugiono.2008.Metode Penelitian Kuantitatif, Kualitatif, dan R\&D.Bandung: Alfabeta.

Umi, Narimawati. 2008.Metode Penelitian Kualitatif, Kuantitatif, Teori, dan Aplikasi. Jakarta: Salemba Empat.

Yusuf, Syamsu. 2011.Psikologi Perkembangan Anak dan Remaja. Bandung: PT Remaja Rosdakarya.

Zoebazary, Ilham. 2010. Kamus Istilah Televisi dan Film. Jakarta: Gramedia. 